incorporate that science.

The European Parliament now gets to battle over the commission's proposals. On 20 June, its energy committee voted to push the cap on food-crop fuels up slightly, to $6.5 \%$. It also removed the stipulation that fuel suppliers report emissions using landuse change figures. Instead, the committee proposed gradually increasing mandates for use of advanced biofuels not made from food crops.

"The science of ILUC is not robust enough for policy," argues Clare Wenner, head of renewable transport policy at the UK Renewable Energy Association in London. But Europe's Joint Research Centre in Brussels says that the models used to calculate the land-use numbers are no less certain than the accepted science on the direct emissions of biofuels - and urges that they be included. The environment committee will vote on its preferred policy on 10 July: its lead negotiator on this issue, Corinne LePage, agrees with the Joint Research Centre and is pushing to incorporate landuse change numbers to distinguish between better and worse food-crop biofuels. But she may not get her way.

The battle does not end there: the main parliament will vote on the issue in September, based largely on what the environment and energy committees recommend. Then Europe's energy ministers will have to reach a compromise on the legislation. Some countries - such as the United Kingdom, the Netherlands and Denmark - want land-use factors to be included, whereas others, including central and eastern European countries with strong biofuel lobbies, do not. Although this month's vote will lay out the main lines of argument, it is conceivable that nothing will be agreed until 2014 - when European Parliament elections in May could set negotiations back to square one. "It's head-bangingly complicated," says Wenner.

\section{CARBON CONUNDRUM}

Indirect land-use change (ILUC) effects mean that some biofuels produce more carbon emissions than fossil fuel.

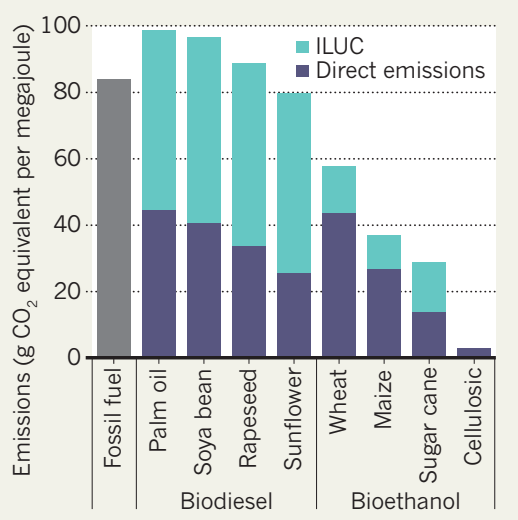

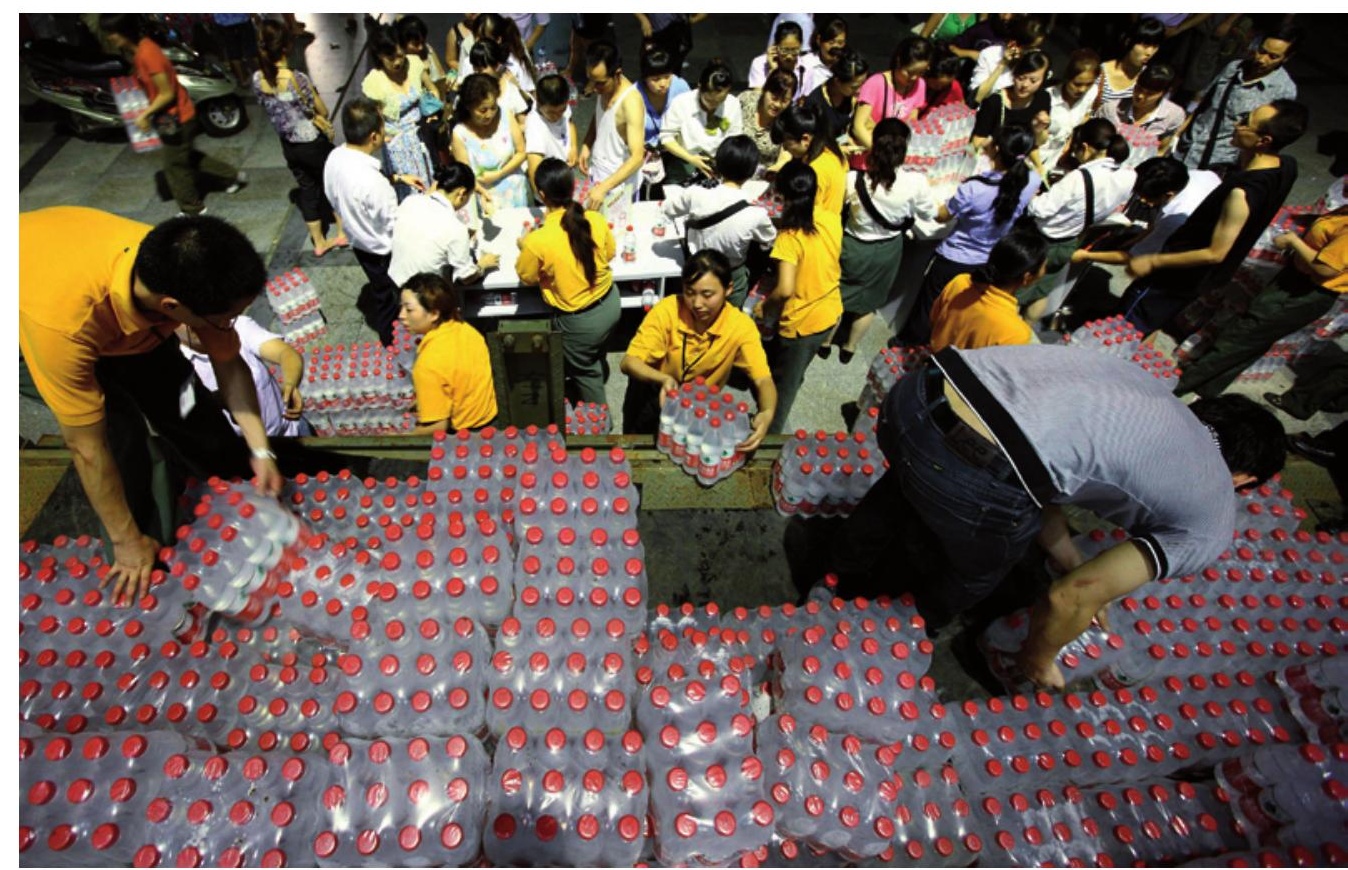

After drinking water was tainted in 2011, people in Mianyang, China, had to take emergency measures.

\title{
ENVIRONMENTAL POLICY
}

\section{China gears up to tackle tainted water}

\section{Government is set to spend 500 million renminbi to clean up groundwater polluted by industry and agriculture.}

\section{BY JIAO LI IN BEIJING}

$\mathrm{W}$ hen rumours swirled earlier this year that factories in Weifang, China, were discharging waste water into the region's aquifers - the principal source of drinking water for the city's 9 million residents - citizens flocked to the Web to register their outrage on microblogging site Sina Weibo. The rumours were finally confirmed by officials in late May, further stoking public fears over an already hot issue: the sorry state of the water that so many Chinese people drink.

Now, a massive government investigation has documented the scope of the problem in northern China, and officials have formulated an ambitious plan to tackle it.

About $18 \%$ of the water that China uses comes from groundwater, and more than 400 of the country's roughly 655 cities have no other source of drinking water. Much of the groundwater is contaminated, tainted by fertilizers, pesticide residues and dirty waste water used for irrigation in China's vast rural regions, as well as pollutants from mining, the petrochemical industry, and domestic and industrial waste. Heavy metals are especially problematic, because "once in the groundwater, they don't go away", says Sun Ge, a research hydrologist at the US Department of Agriculture's Forest Service Southern Research Station in Raleigh, North Carolina. "It will be very expensive to clean up, if it is even possible."

In 2006, to assess the scope of the problem, the Chinese Ministry of Land and Resources launched a 6-year investigation focused on the North China Plain, the region most dependent on groundwater, which is home to nearly 130 million people. In late April this year, the government announced a work plan for control of groundwater contamination in the area. "The work plan is actually quite remarkable, and it is certainly a step in the right direction," says Zheng Yan, who studies groundwater pollution and public health at Columbia University in New York.

The extent of the problem is unclear because the full results of the 2006 survey have not been made public. An

\section{$\rightarrow$ NATURE.COM}

For a call to tackle China's water crisis, visit:

go.nature.com/wxqs3y 
official at the China Geological Survey, which commissioned the report, declined to offer details for fear of alarming the public. However, the government's action plan acknowledges that the levels of pollution are serious. A 2012 report by the land ministry found that of 4,929 groundwater monitoring sites in 198 prefecture-level administrative regions across the country, $41 \%$ had poor water quality. Almost $17 \%$ had extremely poor water quality, with levels of iron, manganese, fluoride, nitrites, nitrates, ammonium and heavy metals exceeding safe limits.

Also last year, an article by Zhang Zhaoji, a hydrogeologist at the Chinese Academy of Geological Sciences' Institute of Hydrology and Environmental Geology in Hebei and project leader for the 2006 survey, reported that in the North China Plain, some 35\% of shallow groundwater sampling points had been contaminated by human activities (Z. Zhang et al. J. Jilin Univ. Earth Sci. Edn 42, 1456-1461; 2012). "Water pollution is a more serious problem than the scarcity of water resources," says Song Xianfang, a hydrologist at the Institute of Geographic Sciences and Natural Resources Research (IGSNRR) in Beijing, part of the Chinese Academy of Sciences.
The contamination rates are "not a surprise, as China is under rapid urbanization and industrialization that bring problems of water pollution for both surface and groundwater", says Sun. And, although it is hard to prove cause and effect, there will probably be fallout for public health, experts say. Government reports stated that in 2004, China had 38.8 million recorded cases of tooth-enamel damage owing to fluoride exposure; 2.84 million cases of bone disease owing to fluoride exposure; and 9,686 cases of arsenic poisoning.

"These diseases are closely related to environmental and geological factors [and are] especially associated with contaminated groundwater," says Yang Linsheng, the director of the department of environmental geography and health at the IGSNRR. The Chinese Center for Disease Control and Prevention did not respond to Nature's request for an interview.

In its plan, the government says that it will divide the North China Plain into 30 units for pollution prevention and control, which it will separate into three severity categories - serious, poor and good - to be addressed differently. The details, which have not been publicly released, include an investment of nearly 500 million renminbi (US\$81 million) between 2013 and 2020 for a raft of measures across the country: to increase pollution assessments and establish a database of results; to control river pollution from agriculture and point sources from industry and landfill; to treat of polluted areas; and to conduct more research into clean-up and prevention strategies. Among other things, researchers will look into the effects of shalegas development on groundwater.

The plan will also beef up environmental regulation. Experts say that will be a key measure, because the country must become more selective in approving industry projects. It must also enhance regulation of polluters, especially small rural companies such as paper mills. Furthermore, farmers must be educated in the proper use of fertilizers. Openness will be crucial in gaining public trust, experts add. "I would advocate data-sharing and transparency in reporting data," says Zheng Chunmiao, director of the Center for Water Research at Peking University in Beijing. "Without this, people will be anxious." -

\section{Evolution makes the grade}

\section{Kansas, Kentucky and other states will also teach climate-change science.}

BY LA LAUREN MORELLO

Dive US states have adopted science education standards that recommend introducing two highly charged topics - climate-change science and evolution - into classrooms well before high school.

Released in April, the Next Generation Science Standards are the first effort in 15 years to overhaul US science education nationwide. Twenty-six states, working with non-profit science and education groups, developed the guidelines on the basis of recommendations from the US National Research Council. And the measures are being adopted, even in states where climate change and evolution tend to be avoided in the classroom.

In the past two months, education officials in Rhode Island, Kentucky, Kansas, Maryland and Vermont have all approved the standards by overwhelming margins. At least five more states - California, Florida, Maine, Michigan

\section{BY DESIGN}

US state legislatures are increasingly introducing 'academic freedom' bills to allow educators to teach creationism. Since 2008, some of these bills would also allow teaching material that promotes climate-change scepticism.

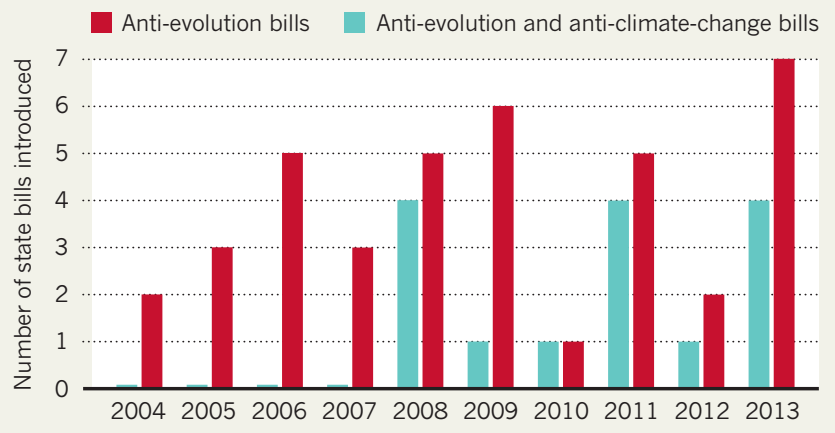

topic in US education for decades, stretching back to the 1925 'monkey trial' in Tennessee, where the state prosecuted high-school teacher John Scopes for violating a statute that barred the teaching of evolution. In the past decade, those who oppose evolution have sought to enact 'academic freedom' laws that would allow creationism to be taught alongside evolution.

Increasingly, that sort of legislation also seeks to promote criticism of mainstream climate science (see 'By design'). Berbeco says that this allows opponents of evolution and climate-change education to band together. "More people hate evo-

and Washington - may take up the standards in the next few months.

"Whew," says Minda Berbeco, programmes and policy director at the National Center for Science Education in Oakland, California. "So far, so good." Swift adoption of the guidelines has been surprising but welcome news for many supporters. Evolution has been a controversial lution and climate change than just evolution alone," she says.

Laws passed in Louisiana in 2008 and in Tennessee last year allow teachers to present material that undermines global warming and evolution, two subjects that have been specifically singled out in the statutes. Similar bills were introduced this year in Arizona, 